\title{
Hubungan Antara Kesesuaian Pemberian Antibiotik Berdasarkan Guideline Terhadap Clinical Outcome pada Pasien Dewasa Dengan Infeksi Mrsa (Methicillin Resistant Staphylococcus aureus) di Rawat Inap RSUP Dr. Sardjito Yogyakarta
}

\author{
Correlation Suitability of Giving Antibiotics Based on Guidelines With Clinical \\ Outcome in Adult Patients With MRSA Infection (Methicillin Resistant \\ Staphylococcus aureus) in Hospitalization RSUP Dr. Sardjito Yogyakarta
}

\author{
Titi Ira Pangestuti1 ${ }^{1}$ Djoko Wahyono ${ }^{2 *}$, Titik Nuryastuti ${ }^{3}$ \\ ${ }_{1}^{1}$ Mahasiswi Magister Farmasi Klinik, Fakultas Farmasi Universitas Gadjah Mada \\ 2 Departemen Farmakologi dan Farmasi Klinik, Fakultas Farmasi Universitas Gadjah Mada \\ ${ }^{3}$ Departemen Mikrobiologi, Fakultas Kedokteran, Kesehatan Masyarakat dan Keperawaran, \\ Universitas Gadjah Mada \\ Corresponding author: Djoko Wahyono: Email: wahyono_djoko@yahoo.com \\ Submitted: 24-07-2019 Revised: 19-09-2019 Accepted: 19-09-2019
}

\begin{abstract}
ABSTRAK
Antibiotik merupakan obat yang harus dapat pengawasan lebih dari tenaga kesehatan dan masyarakat. Banyak pasien yang sudah resisten terhadap golongan antibiotik dengan afinitas tinggi, sehingga menyebabkan terjadinya infeksi nosokomial, salah satunya adalah infeksi MRSA (Methicillin Resistant Staphylococcus aureus). Penelitian ini bertujuan untuk mengevaluasi antibiotik definitif yang digunakan pada pasien MRSA, serta melihat hubungan kesesuaian pemberian antibiotik berdasarkan guideline terhadap clinical outcome pada pasien dewasa dengan infeksi MRSA di rawat inap RSUP Dr. Sardjito Yogyakarta. Rancangan penelitian yang digunakan yaitu observasional deskriptif-analitik, dengan desain cohort retrospektif untuk melihat hubungan kesesuaian penggunaan antibiotik berdasarkan Guideline Keputusan Kementrian Kesehatan Republik Indonesia (Kemenkes RI), Infection Diseases Society of America (IDSA), dan John Hopkin terhadap dengan clinical outcome pasien. Subjek penelitian adalah pasien dewasa dengan infeksi MRSA di rawat inap RSUP Dr Sardjito Yogyakarta periode 1 Januari 2018-31 Mei 2019. Hasil akan dianalisa dengan uji nonparametric test untuk melihat hubungan kesesuaian antibiotik definitif terhadap clinical outcome. Pada penelitian ini didapatkan jumlah sampel yang masuk kriteria inklusi berjumlah 68 pasien. Karakteristik pasien diperoleh rata-rata berumur 47 tahun, pasien terbanyak berjenis kelamin laki-laki yaitu 39 pasien (57,3\%) dan perempuan 29 (42,7\%). Dari 68 pasien, terdapat 74 kasus penyesuaian antibiotik. Jumlah kasus yang sesuai berdasarkan Guideline sebanyak 6 kasus dan ketidaksesuaian sebanyak 68 kasus. Kesimpulan yang didapatkan bahwa tidak terdapat hubungan antara kesesuaian pemberian antibiotik definitif dengan clinical outcome pasien, ditunjukkan dengan penghitungan berdasarkan nonparametric test $(\mathrm{p}>0,05)$.
\end{abstract}

Kata kunci: Antibiotik; MRSA; Dewasa; Infeksi Rumah Sakit

\begin{abstract}
Antibiotics are drugs that must be given more attention to their use in the community and hospitals. Many patients are already resistant to a class of antibiotics with high affinity, causing a more severe infection commonly called a nosocomial infection, one of them is MRSA (Methicillin Resistant Staphylococcus aureus). This study aims to evaluate definitive antibiotics used in MRSA patients, and look at the relationship of suitability of antibiotic administration based on guidelines to clinical outcomes in adult patients with MRSA infection hospitalized at Dr. RSUP Sardjito Yogyakarta. The study design used was observational descriptive-analytic, with a retrospective cohort design to look at the relationship between the suitability of antibiotic administration based on the American Society for Infectious Disease Guidelines (IDSA), the Decree of the Ministry of Health of the Republic of Indonesia (RI Ministry of Health), and John Hopkin of the patient's clinical outcome. The subjects
\end{abstract}


of the study were adult patients with MRSA infection hospitalized Dr. Sardjito General Hospital Yogyakarta period January $1^{\text {st }} 2018$-May $31^{\text {st }} 2019$. The results will be analyzed by nonparametric test to see the relationship between definitive antibiotic suitability to the clinical outcome. In this study, the number of samples included in the inclusion criteria were 68 patients. Characteristics of patients obtained an average of 47 years received, most patients were male, 39 patients (57.3\%) and 29 women $(42.7 \%)$. Sixty eight patients be found 74 cases suitability of antibiotic. The amount of appropriate cases based on Guideline was 6 cases and mismatch as many as 68 cases. The suitability of definitive antibiotic is not related to the significant relationship between definitive antibiotic suitability to patients' clinical outcomes, using calculations based on nonparametric test ( $\mathrm{p}>0.05$ ).

Keywords: Antibiotic; MRSA; Adults; Hospital Infection

\section{PENDAHULUAN}

Masalah kesehatan terkini yang sedang dihadapi dunia terkait angka yang tinggi terhadap morbiditas dan mortalitas penduduk global adalah Methicillin-resistant Staphylococcus aureus (MRSA) (Andaru, 2017) Penyakit ini merupakan suatu infeksi dari bakteri S.aureus, yang menginfeksi pasien ditemukan di rumah sakit pada tahun 1960-an dengan sifat resistensi terhadap antibiotik beta laktam dan saat ini sering ditemukan menjadi patogen yang tahan terhadap antibiotik lain (Ray dkk., 2011).

Kejadian yang banyak perlu pengawasan tenaga kesehatan di dunia maupun Indonesia adalah masalah serius mengenai MRSA, karena tidak sedikit bakteri patogen yang telah resisten terhadap methicillin dan juga berpotensi resisten terhadap antibiotik lain, sehingga berdampak pada tinggi biaya yang ditanggung, serta meningkatkanya angka morbiditas dan mortalitas. Antibiotik memiliki peranan penting di lingkungan rumah sakit, ruangan seperti bangsal di rawat inap dan ruang intensif adalah tempat paling banyak yang menggunakan antibiotik, karena pengobatan dan resistensi dapat berhasil hanya dengan menggunakan antibiotik secara bijak. Penggunaan antibiotik yang tidak tepat dikhawatirkan akan membuat prognosis buruk bagi pasien (Bhargava dkk., 2013).

RSUP Dr. Sardjito pada tahun 2014 di semester-1 memiliki kejadian infeksi MRSA sebesar 13 kasus $(7,27 \%)$, dan mengalami penurunan pada semester-2 2014 menjadi 3 kasus $(1,44 \%)$ (disebutkan menurun berkisar $5,83 \%$ periode pelaksanaan skrining kolonisasi MRSA) (Andaru, 2017). Antibiotik yang diberikan untuk pasien MRSA merupakan antibiotik definitif, sehingga pemberian jenis antibiotiknya sudah jelas menurut pedoman yang digunakan. Penelitian yang dilakukan di rumah sakit China ditemukan infeksi MRSA yang sensitif terhadap antibiotik vancomycin terdiri dari 35 kasus, yaitu sebanyak 13 pasien menggunakan vancomycin tunggal, vancomycin dengan 2 antibiotik terdapat 15 pasien dan vancomycin kombinasi lebih dari 2 antibiotik sebanyak 7 pasien. Diantara jumlah kasus, 27 pasien dinyatakan sembuh, dan 8 pasien dinyatakan gagal sembuh (Tang dkk., 2015).

Penelitian ini dilakukan terkait kesesuaian penggunaan antibiotik pada pasien dewasa yang terinfeksi MRSA dengan clinical outcome pasien. Dalam penelitian ini juga akan dilakukan evaluasi terkait durasi dan dosis yang dapat berpengaruh pada kadar antibiotik di dalam tubuh, sehingga perlu dilakukan suatu penelitian terbaru untuk mendapatkan gambaran mengenai evaluasi kesesuaian penggunaan antibiotik dan clinical outcome pada pasien dewasa MRSA di rawat inap RSUP Dr. Sardjito Yogyakarta.

\section{METODOLOGI}

\section{Rancangan Penelitian}

Penelitian ini bersifat observasional deskriptif-analitik dengan rancangan cohort retrospective yang dilakukan di RSUP Dr. Sardjito Yogyakarta dengan melihat rekam medis pasien bulan 1 Januari 2018 - 31 Mei 2019.

\section{Subyek Penelitian}

Subjek penelitian adalah data catatan rekam medik pasien dewasa yang mengalami infeksi MRSA dan menjalani rawat inap. Kriteria inklusi pasien yaitu pasien dewasa usia $\geq 18$, didiagnosis infeksi MRSA dengan hasil pemeriksaan kultur sensitifitas dan data rekam medis yang lengkap. Sedangkan kriteria ekslusinya adalah pasien yang diberikan antibiotik kurang dari 72 jam. Penelitian ini sudah mendapatkan ethical approval dari Fakultas Kedokteran Universitas Gadjah Mada. 
Tabel I. Karakteristik Pasien MRSA di RSUP Dr. Sardjito Yogyakarta periode 1 Januari 2018 -31 Mei 2019

\begin{tabular}{lcc}
\hline \multicolumn{1}{c}{ Karakteristik } & \multicolumn{2}{c}{ Pasien } \\
\cline { 2 - 3 } & $\mathbf{( n = 6 8 )}$ & $\mathbf{\%}$ \\
\hline Usia (tahun), n(\%) & & \\
18-60 & 53 & 78 \\
>60 Jenis kelamin, n(\%) & 15 & 22 \\
Laki-laki & & \\
Perempuan & 39 & 57,3 \\
LOS (hari), n(\%) & 29 & 42,7 \\
$\quad 3-7$ & & 42,7 \\
$\quad$ 7 hari & 29 & 57,3 \\
\hline
\end{tabular}

\section{Pengumpulan data}

Pengambilan sampel dilakukan dengan teknik purposive sampling. Data karakteristik pasien dikumpulkan berupa umur, berat badan, serum kreatinin pasien, riwayat penyakit, riwayat terapi, tanda-tanda vital, terapi antibiotik yang diterima dan hasil kultur bakteri.

\section{Outcome Clinic}

Outcome clinic yang diamati pada penelitian ini adalah pasien yang dinyatakan membaik, belum sembuh dan meninggal pada bagian lembar resume rekam medik.

\section{Analisis statistik}

Uji statistik penelitian ini menggunakan Statistical Package for the Social Science (SPSS). Data karakteristik pasien, data penggunaan antibiotik, dan kesesuaian penggunaan antibiotik defintif, digambarkan secara deskriptif.

Uji Nonparametric test dengan uji normalitas Kolmogrov-smirnov digunakan untuk melihat hubungan kesesuian penggunaan antibiotik definitif berdasarkan guideline pada pasien dewasa dengan infeksi MRSA terhadap clinical outcome pasien.

\section{HASIL DAN PEMBAHASAN Karakteristik Pasien}

Berdasarkan karakteristik pasien MRSA pada Tabel I, paling banyak terjadi pada usia 1860 tahun yaitu 53 pasien (78\%) sedangkan untuk usia lebih dari 60 tahun sebanyak 15 pasien (22\%). Pasien terbanyak MRSA adalah umur 53 tahun, sejumlah 5 pasien $(7,4 \%)$, dengan rata-rata pasien \pm SD yaitu 47 tahun \pm 17 dan memiliki median 49 tahun.

Usia terbanyak pasien MRSA adalah usia produktif 18 tahun sampai umur 60 tahun. Kerentanan yang lebih besar terhadap suatu infeksi lebih dominan terjadi pada orang tua dibanding dewasa muda. Hal ini dikaitkan dengan sistem kekebalan tubuh yang mengalami penurunan pada pasien dengan umur yang tergolong sudah tidak muda, dan terlebih sistem kekebalan tubuh yang dimediasi oleh sel. Akibat dari frekuensi pasien sering masuk rumah sakit, maka secara tidak langsung berkontribusi dengan masuknya mikroorganisme lain ke dalam tubuh pasien, dan ditambah dengan konsumsi sejumlah obat yang banyak dari sistem rumah sakit (Pomorska-Wesołowska dkk., 2017). Dengan kekebalan tubuh yang semakin rendah punya lebih dari satu jenis penyakit, ditambah dengan aktivitas yang rendah sehingga metabolisme di dalam tubuh berkurang (PomorskaWesołowska dkk., 2017).

MRSA yang dialami oleh laki-laki karena rendahnya standar kebersihan di Indonesia terutama penduduk laki-laki. Kebersihan merupakan faktor dimana infeksi silang dapat terjadi terutama khas pada strain MRSA (Pomorska-Wesołowska dkk., 2017).

\section{Jenis Infeksi MRSA}

Berdasarkan tabel 2, persentase pasien terhadap jenis MRSA dikelompokkan berdasarkan spesimen yang dikultur. Jenis MRSA tertinggi adalah infeksi pada bagian kulit dan jaringan halus kulit, yaitu sebanyak 30 pasien dengan persentase $44,1 \%$. 
Tabel II. Jenis Infeksi Pasien MRSA

\begin{tabular}{lcc}
\hline \multirow{2}{*}{ Jenis Infeksi MRSA } & \multicolumn{2}{c}{ Pasien } \\
\cline { 2 - 3 } & $\mathbf{( n = 6 8 )}$ & $\mathbf{\%}$ \\
\hline Jenis infeksi Methicillin Resistant Staphylococcus aureus, $\mathbf{n}(\mathbf{\%})$ & 44,1 \\
Infeksi kulit dan jaringan lunak & 30 & 25 \\
Bakterimia dan endokarditis & 17 & 14,7 \\
Tulang dan sendi (osteomyelitis) & 10 & 5,9 \\
Pneumonia & 4 & 8,8 \\
Sepsis & 6 & 1,47 \\
Sistem saraf pusat & 1 & 47 \\
\hline
\end{tabular}

\section{Penyakit Penyerta}

Penyakit penyerta infeksi yang terbanyak adalah pneumonia dengan jumlah yang diderita oleh 7 pasien $(10,2 \%)$, dan penyakit penyerta non infeksi yang paling banyak adalah pasien dengan diabetes mellitus dan diikuti dengan hipertensi sebanyak 12 pasien $(17,6 \%)$. Penyakit diabetes mellitus dan hipertensi adalah penyakit dengan permasalahan fungsional dan struktural dalam sistem pembuluh darah arteri maupun kapiler, yang spesifik lebih pada penebalan dinding membran pembuluh darah.

Pada penebalan membran, terjadi kerusakan selaput sehingga respon hiperemik dan migrasi leukosit dihambat. Pada saat jalur sistem pertahanan tubuh dihambat, maka terjadilah vasodilatasi pada bagian luka yang dapat menjadi faktor kerentanan terhadap penyembuhan luka akibat diabetes mellitus. Berawal dari respon neuroinflamasi yang turun, secara tidak langsung pasien diabetes tidak memiliki pertahanan tubuh yang cukup sehingga sangat mudah untuk masuknya penyakit infeksi lain di bagian luka diabetes mellitus (Lima dkk., 2011). Selain hal diatas, banyak pasien adalah pasien pasca bedah. Hal ini dipengaruhi oleh faktor-faktor seperti riwayat operasi, infeksi dan riwayat pengobatan pada pasien yang dapat tersebar kepada tenaga medis dan paramedis yang terjadi lewat kontak dengan pasien MRSA. Faktor kebersihan ruangan, kondisi ruangan fasilitas di dalam ruangan dan perbedaan karakteristik penyakit pasien yang masuk ke dalam ruang bedah termasuk dalam faktor-faktor dari penyebaran infeksi (Raisa Mahmudah, 2013).

\section{Identifikasi Hubungan Kesesuaian Penggunaan Jenis Antibiotik Definitif Terhadap Clinical Outcome}

Kasus Pemberian Antibiotik Definitif Pada Infeksi MRSA

Antibiotik

definitif yang

direkomendasikan Guideline untuk infeksi MRSA yang diberikan dalam kasus, diantaranya adalah antibiotik Doxycycline sebanyak 1 kasus $(1,3 \%)$, Linezolid sebanyak 1 kasus $(1,3 \%)$, Cotrimoxazole sebanyak 4 kasus $(5,4 \%)$, Vancomycin sebanyak 3 kasus (4\%), Clindamisin sebanyak 2 kasus $(2,7 \%)$, serta antibiotik Levofloxasin i.v 5 kasus $(6,7 \%)$ dan Levofloxasin oral 1 kasus (1,3\%), Moxifloxasin sebanyak 2 kasus (2,7\%), dan Gentamisin 1 kasus $(1,3 \%)$ yang dapat digunakan sebagai tambahan dalam pemberian antibiotik kombinasi. Antibiotik pilihan di Indonesia untuk kasus MRSA adalah glikopeptida Vancomycin (Endang, 2011). Vancomycin merupakan antibiotik bakterisidal, dengan mekanisme utama bekerja pada penghambatan biosintesis dinding sel. Selain itu juga vancomycin dapat berpengaruh dalam perubahan permeabilitas membran sel bakteri dan sintesis RNA bakteri. Vancomycin diberikan apabila ada indikasi kebutuhan serius hingga infeksi yang sangat berat yang disebabkan oleh MRSA. Hal ini dapat diartikan dengan indikasi untuk kasus pada pasien-pasien yang alergi antibiotik golongan penisilin, untuk pasien dengan kegagalan respon terhadap antibiotik lain, termasuk antibiotik penisillin atau sefalosporin, dan untuk infeksi yang disebabkan oleh organisme lain yang tidak respon terhadap antibiotik lain (USP, 2015). 
Tabel III. Penyakit Penyerta MRSA

\begin{tabular}{lcc}
\hline \multirow{2}{*}{ Penyakit Penyerta } & Pasien & \% \\
\hline Infeksi, n (\%) & (n=68) & 10,2 \\
Pneumonia & 7 & 7,3 \\
Infeksi Saluran Kemih & 5 & 5,8 \\
TB & 4 & 3 \\
Selulitis & 2 & 3 \\
Diare & 2 & 1,4 \\
Candidiasis & 1 & 1,4 \\
Hepatitis C & 1 & $\mathbf{3 2 , 1}$ \\
Total & $\mathbf{2 2}$ & 17,6 \\
Non Infeksi, n(\%) & & 17,6 \\
Diabetes Mellitus & 12 & 8,8 \\
Hipertensi & 12 & 4,4 \\
Moderate or several renal disease & 6 & 3 \\
Heart disease & 3 & 3 \\
Cerebrovascular disease & 2 & 3 \\
Metastase tumour & 2 & 1,4 \\
Peptic ulcer disease/dispepsia & 2 & 1,4 \\
Bone pain & 1 & 1,4 \\
Delerium & 1 & 1,4 \\
HNP (Hernia nulkolus pulposus) & 1 & 1,4 \\
SLE (Systemic lupus erythematosus) & 1 & $\mathbf{6 5 , 8}$ \\
Status epileptikus & 1 & \\
Traumatic brain & $\mathbf{4 5}$ & \\
Total & \multicolumn{2}{c}{} \\
\hline
\end{tabular}

Evaluasi Kesesuaian Pemberian Antibiotik Definitif Pada Kasus Infeksi MRSA.

Hasil evaluasi kesesuaian penggunaan antibiotik definitif berdasarkan guideline pada kasus infeksi MRSA (gambar 1), Dari 68 pasien didapatkan 74 kasus, antibiotik yang sesuai menurut guideline dilihat dari jenis, dosis, frekuensi, dan durasi antibiotik, didapatkan kesesuaian sebanyak 6 kasus dan 68 kasus tidak sesuai. Kesesuaian berdasar hasil kultur sejumlah 26 kasus. MRSA banyak dinyatakan resistensi terhadap antibiotik beta-laktam penisillin, sefalosporin dan beberapa juga resisten terhadap golongan makrolida, aminoglikosida, dan quinolon, tetapi antibiotik tersebut masih digunakan dan berpengaruh baik pada clinical outcome pasien. Antibiotik beta laktam adalah antibiotik yang umumnya bersifat bakterisid. Antibiotik beta laktam menganggu sintesis dinding sel bakteri, dengan menghambat sintesis peptidoglikan yaitu heteropolimer yang berfungsi stabilizer mekanik pada dinding sel bakteri (Endang, 2011).
Pada pemberian dosis, terdapat 10 kasus yang sesuai dan 6 kasus tidak sesuai. Ketidaksesuaian pemberian dosis ini terdapat antara lain dari 2 kasus yang diberikan antibiotik vancomycin dengan dosis $500 \mathrm{mg}$ tiap 12 jam, sedangkan dosis terapetik vancomycin adalah 15-20 mg/kg tiap 8-12 jam (Liu dkk., 2011). Pemberian dosis yang tidak sesuai dapat dikarenakan beberapa faktor, diantaranya pasien sudah hampir berusia lanjut, faktor yang kedua dapat dilihat dari $\mathrm{ClCr}$ pasien, apabila mendekati angka 40-60 ml/menit maka dosis pemeliharaan dapat diturunkan hingga 50\%. Selain itu pasien dengan penyakit penyerta yang lebih dari 1, sehingga kewaspadaan terhadap pemberian dosis juga perlu diperhatikan (Endang, 2011).

Pada evaluasi frekuensi pemberian antibiotik, pemberian yang tidak sesuai adalah antibiotik Doxycyclin. Doxycycline merupakan antibiotik dengan spektrum luas dan dapat diabsorbsi dengan cepat. Waktu paruh Doxycycline sekitar 5 jam dan waktu yang dibutuhkan untuk mencapai puncak berkisar 


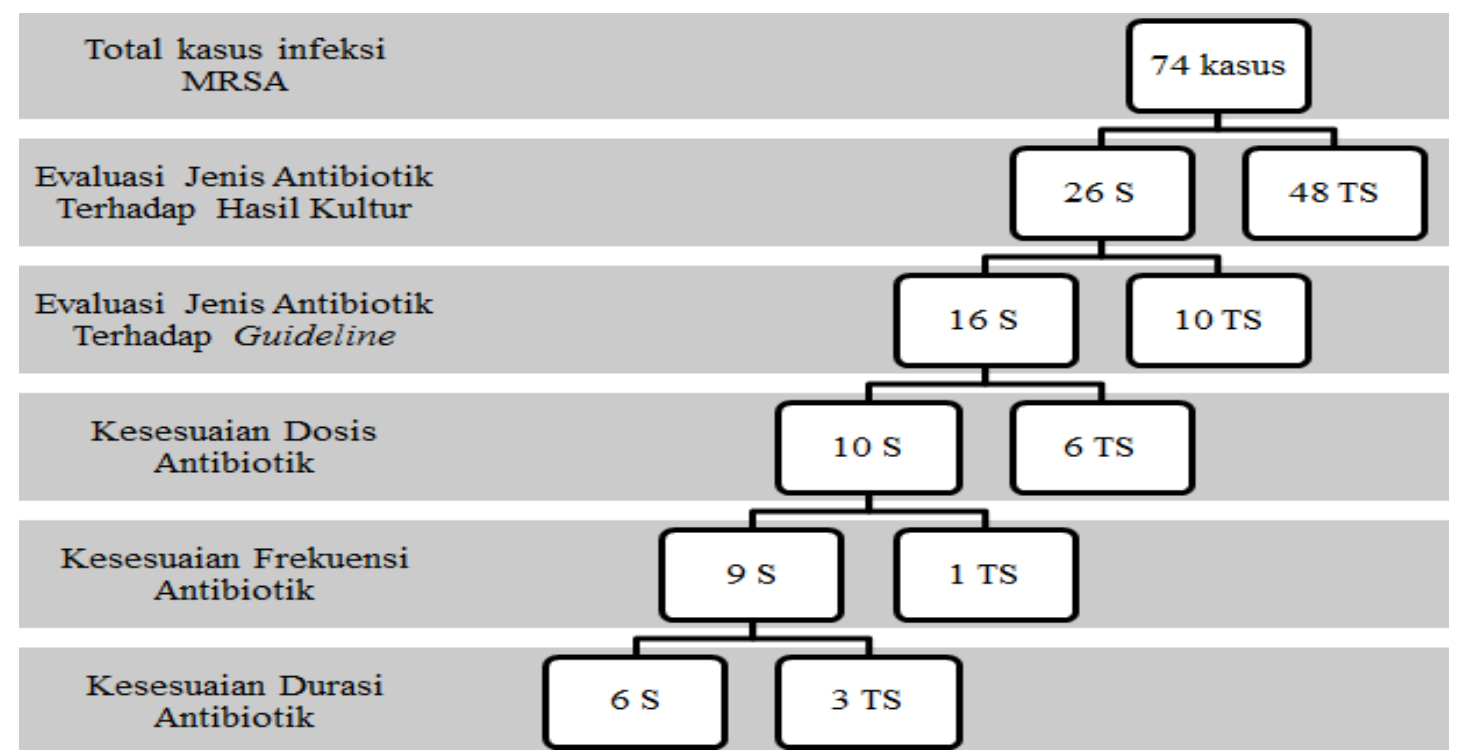

Gambar 1. Bagan Evaluasi Kesesuaian Antibiotik Kasus Infeksi MRSA Terhadap pasien

2 - 3 jam. Oleh karena itu alasan pemberian antibiotik Doxycycline sebaiknya tiap 12 jam agar dapat tercapai kadar minimum hambatnya pada bakteri (Meijer dkk., 2011).

Hubungan Kesesuaian Antibiotik Definitif Dengan Clinical Outcome Pasien

Hasil analisis Nonparametric test terhadap kesesuaian penggunan antibiotik definitif pada pasien dewasa dengan infeksi MRSA di rawat inap RSUP Dr. Sardjito Yogyakarta periode 1 Januari 2018 - 31 Mei 2019 adalah 1,000 (p > 0,05).

Antibiotik yang digunakan dari 74 kasus, sebanyak 6 kasus dinyatakan sesuai dan 68 kasus tidak sesuai, clinical outcome dibagi 3 kelompok dan jumlah masing-masing sebanyak 66 membaik, 2 belum membaik dan 6 kasus meninggal.

Kasus meninggal sebanyak 6 kasus, terdiri dari 4 kasus meninggal diakibatkan sepsis dan 2 kasus disebabkan cardiac arrest. Sepsis merupakan respon sistem kekebalan tubuh yang sudah tidak terkendali terhadap suatu infeksi. Sepsis bisa terjadi pada saat pasien berada di dalam rumah sakit (NICE, 2016). Cardiac arrest atau henti jantung mendadak dapat disebabkan permasalahan terkait paruparu yaitu $27 \%$ thrombosis/pulmonal emboli dan 27\% hipoksia (Bergum dkk., 2015).

Antibiotik definitif adalah pemberian antibiotik yang dilakukan setelah keluarnya kultur, sehingga harus diberikan antibiotik yang sama dengan hasil kultur antibiotik sensitif. Pemberian antibiotik definitif yang tidak sesuai hasil kultur dan sensitivitas, karena dengan antibiotik empiris sudah memberikan clinical outcome yang baik terhadap pasien dewasa dengan infeksi MRSA. Penyembuhan klinis pasien dinyatakan oleh klinisi dengan tandatada klinis dan didukung pemeriksaan mikrobiologi. Apabila tanda-tanda clinical outcome terhadap pasien bagus, maka antibiotik definitif tidak perlu dilakukan pergantian, meski pada hasil kultur dinyatakan bahwa pasien tersebut resisten terhadap antibiotik yang digunakan (Yanuar dkk., 2016).

\section{Farmakokinetik Terhadap Kesesuaian Antibiotik}

Jumlah kasus sesuai sebanyak 6 kasus yang terdiri dari 4 pasien. Cotrimoxazole diberikan secara oral terhadap 2 pasien dengan dosis $960 \mathrm{mg}$ tiap 12 jam. Cotrimoxazole adalah antibiotik yang terdiri dari Trimetoprim dan Sulfametoxazole. Trimetoprim sendiri dapat terdistribusi dengan baik pada jaringan di dalam tubuh dan juga cairan tubuh. Absorbsi obat Cotrimoxazole ini berkisar 90\% - 100\%. Dapat terikat dengan protein sebesar Trimetoprim (TMP) 45\% dan Sulfametoxazol (SMX) 68\%. Waktu paruh TMP adalah 6 - 17 jam, sedangkan SMX yaitu 9 jam. Waktu kadar puncak sekitar 1 - 4 jam (Judith A. Aberg, MD dkk., 2009). 
Antibiotik Linezolid yang digunakan secara intravena diberikan kepada pasien dengan kode P11 dan didapatkan Cmax pasien adalah $26,77 \mathrm{mg} / \mathrm{L}$ dan Cmin pasien adalah 4,92 $\mathrm{mg} / \mathrm{L}$. Hasil Cmin pasien telah masuk rentang MIC Linezolid pada pasien MRSA $(\leq 4 \mathrm{mcg} / \mathrm{mL})$ (CLSI, 2001).

Pasien kedua dengan kode p51 diberikan terapi dengan antibiotik Moxifloxasin. Antibiotik Moxifloxasin didapatkan Cmax pasien adalah 13,52 mg/L dan Cmin pasien adalah 5,1 $\mathrm{mg} / \mathrm{L}$. Hasil Cmin pasien masuk rentang MIC Moxifloxasin pada pasien MRSA $(\leq 0,5 \mathrm{mcg} / \mathrm{mL})$ (CLSI, 2001).

\section{KESIMPULAN}

Perencanaan obat dengan metode konsumsi dan mordibitas, terdapat TPOT untuk mengalisa kebutuhan obat, tetapi proses perencanaan belum berjalan dengan optimal; 2) Pengadaan dilakukan sekali setahun dengan metode $e$-purchasing dengan e-catalogue, $e$ tendering dan pengadaan langsung oleh tim pengadaan ; 3) Manajemen support meliputi struktur organisasi merupakan bagian dari seksi kefarmasian dan alkes, jumlah SDM Apoteker di Puskesmas dan bersertifikat pengadaan terbatas, Pendanaan obat meningkat setiap tahun, Sistem informasi belum berjalan optimal; 4) Faktor-faktor yang menghambat perencanaan dan pengadaan obat adalah kegagalan suplai obat, keterbatasan apoteker dan staf yang memiliki serifikat pengadaan, belum optimalnya sistem informasi e-logistik.

\section{UCAPAN TERIMA KASIH}

Pada penelitian ini Antibiotik MRSA yang digunakan kepada pasien dengan kesesuaian berupa jenis, dosis, frekuensi, dan durasi antibiotik sebanyak 6 kasus yang sesuai berdasarkan Guideline Kemenkes, IDSA, dan John Hopkin dan 68 kasus dinyatakan tidak sesuai. Tidak terdapat hubungan positif antara kesesuaian antibiotik definitif berdasarkan Guideline terhadap clinical outcome pasien, secara statistik $(\mathrm{p}>0,05)$.

\section{DAFTAR PUSTAKA}

Dahesihdewi, A., 2017. Analisis Efektivitas Biaya Pilot Project Skrining Kolonisasi Methicillin-Resistant Staphylococcus Aureus (MRSA) Pada Pasien Ruang Intensif RSUP Dr Sardjito Yogyakarta 13.
Bergum, D., Nordseth, T., Mjølstad, O.C., Skogvoll, E., Dan Haugen, B.O., 2015. Causes Of In-Hospital Cardiac Arrest Incidences And Rate Of Recognition. Resuscitation, 87: 63-68.

Bhargava, D., Deshpande, A., Sreekumar, K., Koneru, G., Dan Rastogi, S., 2013. Guidelines of The Infectious Diseases Society Of America For The Treatment of Methicillin-Resistant Staphylococcus Aureus Infections: As Applied To Oral And Maxillofacial Clinical Practice. Journal Of Maxillofacial And Oral Surgery, 12: 354-358.

CLSI, 2001. Performance Standards For Antimicrobial Susceptibility Testing. Clinical Microbiology Newsletter, 23: 49.

Endang Rahayu Sedyaningsih, 2011. Peraturan Menteri Kesehatan Republik Indonesia Nomor 2406/Menkes/Per/XII/2011. Pedoman Umum Penggunaan Antibiotik. Jakarta

FDA, 2011. 'Methicillin-Resistant Staphylococcus Aureus. Therapy: Past, Present, And Future | Oxford Academic',s. URL: Https://Academic.Oup.Com/ViewLarge/97958349 (Diakses Tanggal 27/11/2018).

Food And Drug Administration, 2013. Meropenem For Injection.

Gonzales, P.R., Pesesky, M.W., Bouley, R., Ballard, A., Biddy, B.A., Suckow, M.A., Dkk., 2015. Synergistic, Collaterally Sensitive BLactam Combinations Suppress Resistance In MRSA. Nature Chemical Biology, 11: 855-861.

Judith A. Aberg, MD, William Alvarez Jr., BS, Pharmd, Rph, Lora Armstrong, Rph, Pharmd, BCPS, Kenneth A. Bachmann, Phd, FCP, Dan Verna L. Baughman, MD, 2009. Drug Information Handbook, 17th Edition.Chm.

Lima, A.F., Costa, L.B., Silva, J.L. Da, Maia, M.B.S., Dan Ximenes, E.C.P.A., 2011. Interventions For Wound Healing Among Diabetic Patients Infected With Staphylococcus Aureus: A Systematic Review. Sao Paulo Medical Journal, 129: 165-170.

Liu, C., Bayer, A., Cosgrove, S.E., Daum, R.S., Fridkin, S.K., Gorwitz, R.J., Dkk., 2011. Clinical Practice Guidelines By The Infectious Diseases Society Of America For The Treatment of Methicillin- 
Resistant Staphylococcus Aureus Infections In Adults And Children. Clinical Infectious Diseases, 52: E18-E55.

Menteri Kesehatan Republik Indonesia, 2011. Pedoman Umum Penggunaan Antibiotik.

NICE, 2016. Sepsis : Recognition, Diagnosis And Early Management. England. 5

Pomorska-Wesołowska, M., Różańska, A., Natkaniec, J., Gryglewska, B., Szczypta, A., Dzikowska, M., Dkk., 2017. Longevity And Gender As The Risk Factors of Methicillin-Resistant Staphylococcus Aureus Infections In Southern Poland. BMC Geriatrics, 17

Raisa Mahmudah, 2013. Identifikasi MethicillinResistant Staphylococcus Aureus (Mrsa) Pada Tenaga Medis Dan Paramedis Di Ruang Intensivecare Unit (Icu) Dan Ruang Perawatan Bedah Rumah Sakit Umum Daerah Abdul Moeloek.

Raisa Mahmudah, Dr. Tri Umiana Soleha, Dan Dra. CN Ekowati, 2013. 'Identifikasi Methicillin-Resistant Staphylococcus Aureus (Mrsa) Pada Tenaga Medis Dan Paramedis Di Ruang Intensivecare Unit (Icu) Dan Ruang Perawatan Bedah Rumah Sakit Umum Daerah Abdul Moeloek | Mahmudah | Jurnal Majority',. URL: (Diakses Tanggal 11/11/2018).
Ray, P., Gautam, V., Dan Singh, R., 2011. Methicillin-Resistant Staphylococcus Aureus (MRSA) In Developing And Developed Countries: Implications And Solutions 15: 9.

Tang, J., Hu, J., Kang, L., Deng, Z., Wu, J., Dan Pan, J., 2015. The Use Of Vancomycin In The Treatment of Adult Patients With Methicillin-Resistant Staphylococcus Aureus (MRSA) Infection: A Survey In A Tertiary Hospital In China 6.

USP, 2015. Vancomycin Injection, USP 2.Pdf.

Wirapakorn C, Singkham U-In, Sujittra T, Surawut S, Visitchanakun P, Chatsuwan, Dkk., 2019. The Cooperation Of Pharmacologic-Dose Ascorbate With Ceftriaxone Against Staphylococcus Aureus Through Bactericidal Synergy And Enhanced Macrophage Killing Activity. Asian Pacific Journal of Allergy And Immunology, .

Yanuar, W., Puspitasari, I., Dan Nuryastuti, T., 2016. Evaluasi Kesesuaian Antibiotik Definitif Terhadap Clinical Outcome Pada Pasien Anak Dengan Meningitis Bakterial Di Bangsal Rawat Inap Rumas Sakit Umum Pusat 6: 18. 